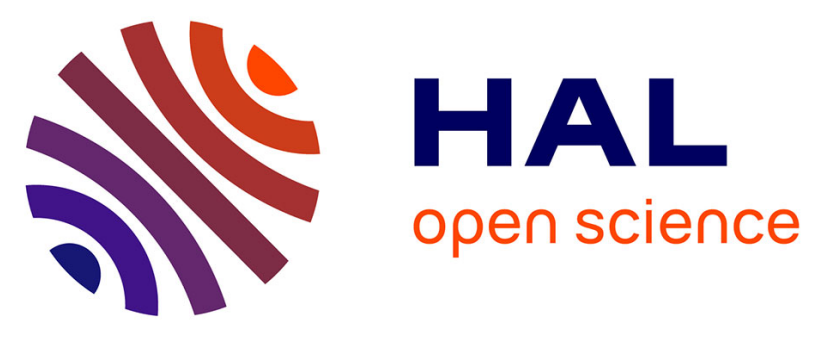

\title{
Native Ion Mobility Mass Spectrometry: When Gas-Phase Ion Structures Depend on the Electrospray Charging Process
}

\author{
Nina Khristenko, Jussara Amato, Sandrine Livet, Bruno Pagano, Antonio \\ Randazzo, Valérie Gabelica
}

\section{To cite this version:}

Nina Khristenko, Jussara Amato, Sandrine Livet, Bruno Pagano, Antonio Randazzo, et al.. Native Ion Mobility Mass Spectrometry: When Gas-Phase Ion Structures Depend on the Electrospray Charging Process. Journal of The American Society for Mass Spectrometry, 2019, 30 (6), pp.1069-1081. 10.1007/s13361-019-02152-3 . hal-02358221

\section{HAL Id: hal-02358221 \\ https://hal.science/hal-02358221}

Submitted on 11 Nov 2019

HAL is a multi-disciplinary open access archive for the deposit and dissemination of scientific research documents, whether they are published or not. The documents may come from teaching and research institutions in France or abroad, or from public or private research centers.
L'archive ouverte pluridisciplinaire HAL, est destinée au dépôt et à la diffusion de documents scientifiques de niveau recherche, publiés ou non, émanant des établissements d'enseignement et de recherche français ou étrangers, des laboratoires publics ou privés. 


\title{
Native Ion Mobility Mass Spectrometry: when Gas Phase Ion Structures Depend on the Electrospray Charging Process
}

\author{
Nina Khristenko, ${ }^{1}$ Jussara Amato, ${ }^{2}$ Sandrine Livet, ${ }^{1}$ Bruno Pagano, ${ }^{2}$ Antonio Randazzo, ${ }^{2}$ \\ Valérie Gabelica ${ }^{1 *}$ \\ 1 Laboratoire Acides Nucléiques: Régulations Naturelle et Artificielle, Université de \\ Bordeaux, Inserm \& CNRS (ARNA, U1212, UMR5320), IECB, 2 rue Robert Escarpit, 33607 \\ Pessac, France. \\ 2 Department of Pharmacy, University of Naples Federico II, via Domenico Montesano 49, \\ 80131, Naples, Italy.
}

Corresponding author: v.gabelica@iecb.u-bordeaux.fr

\begin{abstract}
Ion mobility spectrometry (IMS) has become popular to characterize biomolecule folding. Numerous studies have shown that proteins that are folded in solution remain folded in the gas phase, whereas proteins that are unfolded in solution adopt more extended conformations in the gas phase. Here, we discuss how general this tenet is. We studied single-stranded DNAs (human telomeric cytosine-rich sequences with CCCTAA repeats), which fold into an intercalated motif (i-motif) structure in a $\mathrm{pH}$-dependent manner, thanks to the formation of $\mathrm{C}-\mathrm{H}^{+}-\mathrm{C}$ base pairs. As i-motif formation is favored at low ionic strength, we could investigate the ESI-IMS-MS behavior of $\mathrm{i}$-motif structures at $\mathrm{pH} \sim 5.5$ over a wide range of ammonium acetate concentrations (15 mM to $100 \mathrm{mM})$. The control experiments consisted of either the same sequence at $\mathrm{pH} \sim 7.5$, wherein the sequence is unfolded, or sequence variants that cannot form i-motifs (CTCTAA repeats). The surprising results came from the control experiments. We found that the ionic strength of the solution had a greater effect on the compactness of the gas-phase structures than the solution folding state. This means that electrosprayed ions keep a memory of the charging process, which is influenced by the electrolyte concentration. We discuss these results in light of the analyte partitioning between the droplet interior and droplet surface, which in turn influences the probability of being ionized via a charged residue-type pathway or a chain extrusion-type pathway.
\end{abstract}




\section{Introduction}

In addition to the well-known Watson-Crick double helix, nucleic acids can form several non-canonical structures, which are likely involved in the regulation of gene expression. One of them is the i-motif (intercalated motif) structure [1-4], formed by cytosine-rich DNA sequences, wherein the strands are inter-connected by intercalated hemiprotonated $\mathrm{C}-\mathrm{H}^{+}-\mathrm{C}$ base pairs (Figure 1). i-motif formation is $\mathrm{pH}$-dependent, and the $\mathrm{pH}$ of mid-transition from i-motif to unfolded structure depends on the C-tract length. The interest in i-motifs was boosted by recent reports showing that i-motifs can form in vitro in at physiological $\mathrm{pH}$ [5], in the genomic DNA of the nuclei of fixed cells [6] and in DNA constructs introduced in the nuclei of living cells [7].

The typical biophysical methods to probe the presence of i-motifs in solution are UV absorption spectroscopy [8] (i-motifs have a higher molar extinction coefficient at $295 \mathrm{~nm}$ than single strands), circular dichroism spectroscopy [9] (maximum $\Delta \varepsilon$ at $295 \mathrm{~nm}$ and minimum at $260 \mathrm{~nm}$ ), and NMR (imino ${ }^{1} \mathrm{H}$ signals around $15-16 \mathrm{ppm}$ for the $\mathrm{C}-\mathrm{H}^{+}-\mathrm{C}$ base pair, and unusual inter-residue sugar-sugar NOEs H1'-H1', H1'-H2" and H1'-H4' [1]). Here we evaluated whether electrospray ion mobility mass spectrometry could be used to assess whether a sequence is folded or not into an i-motif in solution.
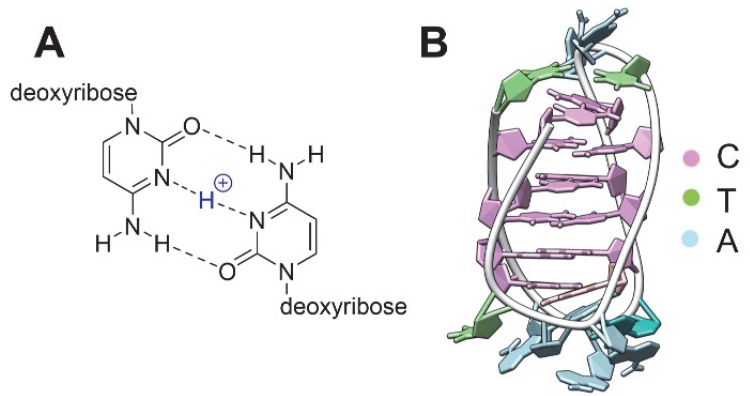

Figure 1. A) Hemiprotonated $\mathrm{C}-\mathrm{H}^{+}-\mathrm{C}$ base pair. B) The i-motif structure of the human telomeric DNA sequence d(CCCTAA) ${ }_{3}$ CCCT resolved using NMR (BDP: 1EL2) [10].

The coupling of ion mobility spectrometry to mass spectrometry [11-14] has indeed opened new avenues for the characterization of biomolecules by mass spectrometry. The mass alone does not indicate the conformation, but ion mobility spectrometry (IMS) separates ions 
according to their electrophoretic mobility in a buffer gas, and hence, for each charge state, according to their compactness. IMS thus directly probes the conformation of gas-phase ions. For biomolecule mass spectrometry, the other historical landmark was the introduction of electrospray ionization $[15,16]$, which transfers intact analytes to the mass spectrometer directly from solutions and confers them one or several charges [17]. It was soon realized that non-covalent interactions could be preserved upon electrospray [18, 19], and this paved the way for "native" ESI-MS [20], wherein one uses the least possibly energetic instrumental conditions to preserve weak non-covalent bonds present in solution, and then probe the secondary, tertiary and/or quaternary structures in the gas phase.

An important fundamental question underlying native MS is thus how biomolecule structures are affected while the analytes get charged and desolvated during electrospray. As electrospray generally preserves intramolecular non-covalent interactions, and as ion mobility spectrometry probes gas-phase compactness, it seems logical that ion mobility spectrometry should probe the compactness of solution phase structures. Several studies have validated this logic by showing that folded structures in solution end up compact in the gas phase, while unfolded structures in solution end up much more extended in the gas phase [21-23]. However, the electrospray (charging) mechanism also plays a role in the gas-phase conformation. Indeed, unfolded structures in solution generally end up adopting higheer charge states than disordered structures [24-27], and Coulomb repulsion between like charges may also cause gas-phase unfolding. If Coulomb repulsion overcomes the native intramolecular interactions, the resulting conformation in the gas-phase will be extended. The opposite is also possible: if Coulomb repulsion is not high enough, non-native non-covalent contacts (not pre-existing in solution) can form in the gas phase and the resulting conformation will be compact. Such gas-phase compaction at low charge states was observed in partially re-neutralized unfolded proteins [28, 29], in antibodies [30, 31], and in nucleic acid duplexes [32]. A fundamental question in electrospray is thus also what drives a large molecule to adopt a given charge state.

Here we report intriguing effects of the electrospray process, modulated by the electrolyte concentration more than by solution pre-folding, on the ion mobility of DNA polyanions. We showed previously by IRMPD ion spectroscopy that electrosprayed i-motif structures preserved the $\mathrm{C}-\mathrm{H}^{+}-\mathrm{C}$ base pairs, at least for low charge states (4- to 6-) [33]. However, Fernandez-Lima and collaborators had found no difference in ion mobility profiles of the human telomeric i-motif sequence $\mathrm{d}(\mathrm{CCCTAA})_{3} \mathrm{CCC}$ in $10 \mathrm{mM} \mathrm{NH}_{4} \mathrm{OAc}$ as a function of the 
$\mathrm{pH}$ [34], casting doubt on the potential utility of ESI-IMS-MS to study i-motif solution folding. Here, we show that the ion mobility spectra depend strongly on the electrolyte $\left(\mathrm{NH}_{4} \mathrm{OAc}\right)$ concentration used for electrospray, and we show the importance of control experiments (different $\mathrm{pH}, \mathrm{NH}_{4} \mathrm{OAc}$ concentrations, activation energies, and experiments with control sequences) to infer information on the solution structures from ion mobility measurements.

\section{Materials and Methods}

\section{$D N A$}

All strands were purchased from either IDT (Leuven, Belgium, HPLC purification) or Eurogentec (Seraing, Belgium, with RP cartridge - Gold ${ }^{\mathrm{TM}}$ purification), dissolved in nuclease-free water from Ambion (Applied Biosystems, Lennik, Belgium), and used without further purification. The stock concentrations were determined using the Beer-Lambert law. The absorbance was recorded at $260 \mathrm{~nm}$ on a Uvikon XS, and molar extinction coefficients calculated using the IDT website by applying the Cavaluzzi-Borer Correction [35].

$\mathrm{dT}_{6}(\mathrm{MM}=1763.2)$ and $\mathrm{dTG}_{4} \mathrm{~T}(\mathrm{MM}=1863.3)$ were used to verify the instrument each day for the determination of collision cross section (CCS) values $\left({ }^{\mathrm{DT}} \mathrm{CCS}_{\mathrm{He}}=306 \AA^{2}\right.$ for $\mathrm{dT}_{6}{ }^{2-}$, see supporting information of [36], and $788 \AA^{2}$ for $\left.\left[\left(\mathrm{dTG}_{4} \mathrm{~T}\right)_{4}\left(\mathrm{NH}_{4}\right)_{3}\right]^{5-}[37]\right)$. The $\left[\left(\mathrm{dTG}_{4} \mathrm{~T}\right)_{4}\left(\mathrm{NH}_{4}\right)_{3}\right]$ G-quadruplex was formed in $150 \mathrm{mM}$ ammonium acetate from $200 \mu \mathrm{M}$ single strand, incubated overnight at $4^{\circ} \mathrm{C}$. Final solution used in IMS analysis contained 150 $\mathrm{mM} \mathrm{NH} 4 \mathrm{OAc}, 2.5 \mu \mathrm{M} \mathrm{dT}_{6}$ and $5 \mu \mathrm{M}\left[\left(\mathrm{dTG}_{4} \mathrm{~T}_{4}\right)_{4}\left(\mathrm{NH}_{4}\right)_{3}\right]$. The C-rich oligodeoxynucleotides

$\mathrm{d}\left[(\mathrm{CCCTAA})_{3} \mathrm{CCC}\right](21 \mathrm{C}, \mathrm{MM}=6200.1), \mathrm{d}\left[(\mathrm{CTCTAA})_{3} \mathrm{CTC}\right](21 \mathrm{CTC}, \mathrm{MM}=6260.2)$, $\mathrm{d}[(\mathrm{TAACCC}) 5]$ (30C, $\mathrm{MM}=8928.9)$ and d[(TAACTC)5] (30CTC, $\mathrm{MM}=9003.9)$ were used for the native IM-MS study. Samples were prepared at $20 \mu \mathrm{M}$ single strand concentration in 15,50 or $100 \mathrm{mM}$ ammonium acetate at two $\mathrm{pH}$ values 5.5 and 7.5, and let fold overnight at $4{ }^{\circ} \mathrm{C}$. Acetic acid or ammonium hydroxide were used to adjust the $\mathrm{pH}$. The $\mathrm{pH}$ was measured using a Multi9420 digital pH conductivity meter (WTW, Weilheim, Germany) calibrated on the day of measurement.

\section{Ion mobility spectrometry-mass spectrometry}

Experiments were performed on an Agilent 6560 DTIMS-Q-TOF instrument (Agilent Technologies, Santa Clara, CA), equipped with the dual-ESI source operated in the negative 
ion mode. The DNA solutions were injected at $20 \mu \mathrm{M}$ strand concentration. The pre-IMS introduction conditions were optimized for softness as described elsewhere [38]. The drift tube was filled with helium and the pressure was fixed at $3.89 \pm 0.01$ Torr, measured accurately by a capacitance diaphragm gauge (CDG-500, Agilent Technologies). The following IMS parameters were used fragmentor $250 \mathrm{~V}$, trap fill time $1000 \mu \mathrm{s}$, trap release time $100 \mu \mathrm{s}$, trap entrance grid delta (TEGD) $2 \mathrm{~V}$. For the CCS determination, the step-field experiment included 5 segments $(1 \mathrm{~min}$ each) where drift tube entrance voltage was $-600 \mathrm{~V}$, $-700 \mathrm{~V},-800 \mathrm{~V},-900, \mathrm{~V},-1000 \mathrm{~V}$. For CIU experiments, the drift tube entrance voltage was fixed at $-600 \mathrm{~V}$, and the activation was performed by varying the TEGD voltage from 1 to $12 \mathrm{~V}$.

The IMS data were extracted using the IM-MS Browser software version B.06.01 (Agilent Technologies). The arrival time and signal intensity was extracted for the $m / z$ range of interest (encompassing the isotopic distribution of the non-adducted species) using in-house RStudio script. For the CIU data processing, the intensities in each IMS segment were normalized by the maximum intensity in a given segment. All figures were prepared using SigmaPlot or OriginPro softwares.

In order to estimate the CCS values the ion mobility peaks were fitted by Gaussian functions using PeakFit v4.11 (Systat Softwares, San Jose, CA). The arrival time for the center of each peak was determined for each segment and plotted as a function of the inverse of the drift voltage $\Delta \mathrm{V}$, to extract the CCS value from the slope according to Equation (1).

$$
t_{a}=t_{0}+\operatorname{CCS} \cdot\left(\frac{L^{2} N_{0} \frac{T_{0} p}{T p_{0}}}{\frac{3 z e}{16} \sqrt{\frac{2 \pi}{\mu k_{B} T}}}\right) \cdot \frac{1}{\Delta V}
$$

Where $t_{a}$ is the measured arrival time, $t_{0}$ is the time spent outside the drift tube and is deduced from the intercept, $L$ length of the mobility cell $(\mathrm{L}=78.1 \mathrm{~cm}), \mu$ is the reduced mass of the analyte/gas couple, $k_{B}$ the Boltzmann constant, $T$ the temperature $\left(\mathrm{T}=23.5 \pm 1{ }^{\circ} \mathrm{C}\right), p$ the pressure in the drift tube ( $p=3.89 \pm 0.01$ Torr), $N_{0}=2.687 \times 10^{25} \mathrm{~m}^{-3}, P_{0}=760$ Torr and $T_{0}=273.15 \mathrm{~K}$.

\section{Circular dichroism spectroscopy}

$\mathrm{CD}$ experiments were performed on solutions prepared following the same protocol as for ESI-IM-MS. CD spectra were recorded on spectrophotometer Jasco J-1500 at $20^{\circ} \mathrm{C}$. The 
measured CD ellipticity ( $\theta$, in milidegrees) was transformed to molar circular dichroic absorption $(\Delta \varepsilon)$ using Equation (2):

$$
\Delta \varepsilon=\frac{\theta}{32980 \times C \times l}
$$

where $C$ is the DNA concentration in mol/L $\left(C=2 \times 10^{-5} \mathrm{~mol} / \mathrm{L}\right)$ and $l$ is the path length in $\mathrm{cm}(l=0.2 \mathrm{~cm})$.

\section{Thermal denaturation}

The UV absorbance of DNA sequences was recorded as a function of temperature using SAFAS UV mc2 spectrophotometer (Monaco). The DNA concentration in the ammonium acetate solutions was $10 \mu \mathrm{M}$, to avoid saturation. The temperature ramp was $0.2^{\circ} \mathrm{C} / \mathrm{min}$ from 4 to $90{ }^{\circ} \mathrm{C}$ and back to $4{ }^{\circ} \mathrm{C}$. The absorbance was monitored at $295 \mathrm{~nm}$.

\section{Nuclear magnetic resonance}

NMR spectra were recorded on a Varian Unity INOVA $700 \mathrm{MHz}$ spectrometer equipped with a cryo-probe unit. One-dimensional proton spectra were recorded at $10{ }^{\circ} \mathrm{C}$ using the pulsedfield gradient DPFGSE for water suppression. The oligonucleotides $\mathrm{d}\left[(\mathrm{CCCTAA})_{3} \mathrm{CCCT}\right]$ and $\mathrm{d}\left[(\text { CTCTAA })_{3} \mathrm{CTC}\right]$ were prepared at $0.25 \mathrm{mM}$ concentration in $0.2 \mathrm{~mL}$ of solution $\left(\mathrm{H}_{2} \mathrm{O} / \mathrm{D}_{2} \mathrm{O}\right.$ 9:1) containing 15,50 or $150 \mathrm{mM}$ ammonium chloride at $\mathrm{pH} 5.7$ and 7.0. NMR data were processed on an iMAC running iNMR software (www.inmr.net).

\section{Results}

\section{Solution folding of the human telomeric i-motif sequence d(CCCTAA) $)_{3} \mathrm{CCC}$, and controls}

The well-studied telomeric C-rich DNA sequence $21 \mathrm{C}\left(\mathrm{d}(\mathrm{CCCTAA}){ }_{3} \mathrm{CCC}\right)$ was used as a model $\mathrm{i}$-motif structure. We analyzed $21 \mathrm{C}$ at $\mathrm{pH}=5.5$ and at $\mathrm{pH}=7.5$. We also studied the control DNA sequence 21CTC (d(CTCTAA) 3 CTC), which is not supposed to form an i-motif at any $\mathrm{pH}$. We conducted classical spectroscopy analyses to confirm the formation / absence of i-motif structure in electrospray-compatible $\mathrm{NH}_{4} \mathrm{OAc}$ solutions of different ionic strengths.

The CD spectra of $21 \mathrm{C}$ at $\mathrm{pH} 5.5$ showed a profile characteristic of i-motif structure with a positive peak around $290 \mathrm{~nm}$ and negative peak at $260 \mathrm{~nm}$, and were very similar for 
solutions with different ionic strengths (Figure $2 \boldsymbol{A}$ ). The CD spectra recorded at $\mathrm{pH} 7.5$ presented the decrease in intensity and blue shift of positive peak - a profile assigned to random coil structure in previous studies [39] (Figure 2B). Also, CD spectra at pH 7.5 were similar between solutions with different ammonium acetate concentration. The CD spectra of 21CTC at pH 5.5 (Figure 2C) or 7.5 (supplementary Figure S1) were similar with CD of $21 \mathrm{C}$ at $\mathrm{pH} 7.5$, i.e. the profile corresponding to a random coil structure.

The thermal denaturation data showed the predominance of the i-motif structure at $\mathrm{pH} 5.5$ at room temperature for all ammonium acetate concentrations (Figure $2 D$ ). Interestingly, decreasing the $\mathrm{NH}_{4} \mathrm{OAc}$ concentration increases the i-motif stability: the melting transition occurs at a higher temperature in $15 \mathrm{mM}$ NH4OAc (black curve) than in $100 \mathrm{mM} \mathrm{NH4OAc}$ (blue curve). This is a known behavior of i-motif structures [40]: in i-motifs there must be a subtle balance between screening of the phosphate groups and changes in local pKa of the cytosines, and thus in contrast to double helices, i-motifs are more stable at lower ionic strength. The melting analysis of $21 \mathrm{C}$ at $\mathrm{pH} 7.5$ and $21 \mathrm{CTC}$ at $\mathrm{pH} 5.5$ showed low absorbance at $295 \mathrm{~nm}$ and no melting, suggesting the absence of i-motif (Figure $2 \boldsymbol{E}-\boldsymbol{F}$ ). NMR spectroscopy was further employed to investigate the i-motif formation in solutions with ammonium concentrations ranging from 15 to $150 \mathrm{mM}$. The sequence $\mathrm{d}(\mathrm{CCCTAA})_{3} \mathrm{CCCT}$ (named 22CT), containing one additional thymine at 3'-end, was used for these experiments because it has been well characterized by NMR [10, 41]. The imino and aromatic proton regions of 22CT and 21CTC are shown in Figure $2 \boldsymbol{G}-\boldsymbol{I}$. Regardless of the ionic strength, 22CT forms a well-defined i-motif structure at slightly acidic $\mathrm{pH}$ (5.7), characterized by three well-resolved imino protons peaks between 15 and $15.5 \mathrm{ppm}$, corresponding to the six intercalated $\mathrm{C}-\mathrm{H}^{+}-\mathrm{C}$ pairs (Figure $2 \boldsymbol{G}$ ). In addition, the aromatic proton region of $22 \mathrm{CT}$ at $\mathrm{pH} 5.7$ matches well with that reported in literature for the telomeric i-motif structure [10]. Regardless of ammonium concentration, no imino proton signals (whether for $\mathrm{C}-\mathrm{H}^{+}-\mathrm{C}$ base pairs or any other base pairs) were detected for $22 \mathrm{CT}$ at neutral pH, as well as for 21CTC at acidic pH (Figure $\mathbf{2 H - I}$ ), clearly indicating the absence of secondary structures in these cases. The DINAMelt web server was used to find possible sub-optimal structures [42]. The only predicted sub-optimal structures had at most two AT base pairs, with melting temperatures below $-30^{\circ} \mathrm{C}$ in $100 \mathrm{mM}$ salt. It does not mean that single strand do not adopt some preferential conformations involving the stacking of adjacent bases [43]. In fact, CD data show a positive band around 270-280 $\mathrm{nm}$ and a negative one at $250 \mathrm{~nm}$, indicating that the single strand is not totally a random coil. 
Therefore, $21 \mathrm{C}$ at $\mathrm{pH}=7.5$ and $21 \mathrm{CTC}$ at $\mathrm{pH}=5.5$ do not form $\mathrm{i}$-motif structures and will be considered as our negative controls. An important point for the coming discussion is that the NMR spectra or CD spectra of both the i-motifs and the single-stranded DNAs are unaffected by the $\mathrm{NH}_{4}{ }^{+}$concentration (this also holds for the aromatic proton region at $7-8 \mathrm{ppm}$ ). Thus, if IM-MS data reflect the solution folding, we would anticipate the IM-MS results to be the same at all $\mathrm{NH}_{4} \mathrm{OAc}$ concentrations.
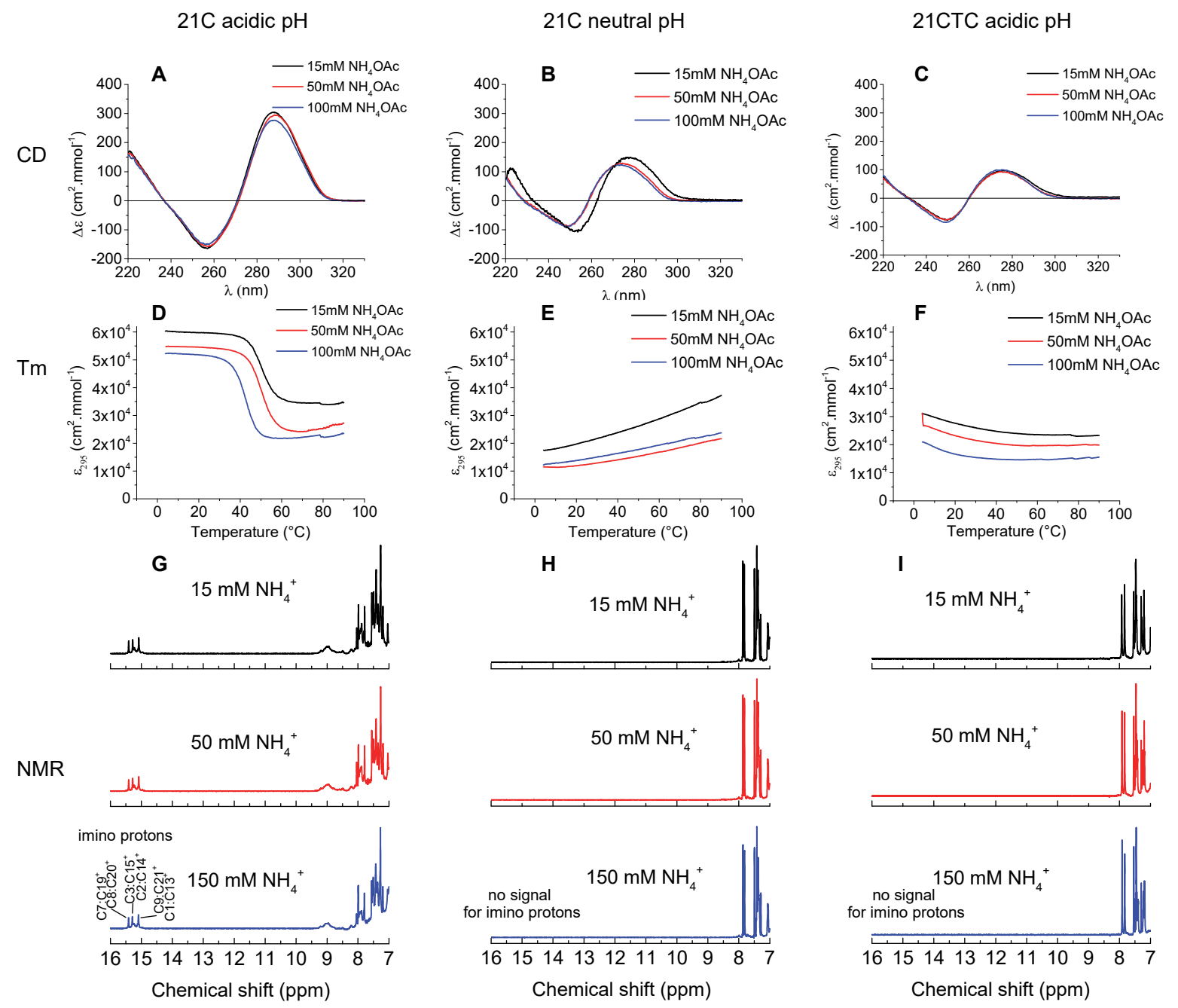

Figure 2. $\boldsymbol{A}$-C) $\mathrm{CD}$ spectra of $21 \mathrm{C}$ at $\mathrm{pH} 5.5(\boldsymbol{A}), 21 \mathrm{C}$ at $\mathrm{pH} 7.5(\boldsymbol{B})$ and $21 \mathrm{CTC}$ at $\mathrm{pH} 5.5$ (C) in 15, 50 and $100 \mathrm{mM}$ of $\mathrm{NH}_{4} \mathrm{OAc}$. $\boldsymbol{D}$-F) Thermal denaturation (Tm) monitored by the absorbance at $295 \mathrm{~nm}$ for $21 \mathrm{C}$ at $\mathrm{pH} 5.5(\boldsymbol{D}), 21 \mathrm{C}$ at $\mathrm{pH} 7.5(\boldsymbol{E})$ and $21 \mathrm{CTC}$ at $\mathrm{pH} 5.5(\boldsymbol{F})$ in 15,50 and $100 \mathrm{mM}$ of $\mathrm{NH}_{4} \mathrm{OAc}$. G-I) ${ }^{1} \mathrm{H}$ NMR spectra of $21 \mathrm{C}$ at $\mathrm{pH} 5.5(\boldsymbol{G}), 21 \mathrm{C}$ at $\mathrm{pH} 7.5$ (H) and $21 \mathrm{CTC}$ at $\mathrm{pH} 5.5$ (I) in 15,50 and $150 \mathrm{mM}$ of $\mathrm{NH}_{4} \mathrm{Cl}$. CD and melting data for $21 \mathrm{CTC}$ at $\mathrm{pH}=7.5$ are shown in Supplementary Figure S1. 


\section{Electrospray mass spectra of the 21-mer i-motif and its controls}

Mass spectra of $21 \mathrm{C}$ and $21 \mathrm{CTC}$ acquired at three $(15,50$ and $100 \mathrm{mM})$ concentrations of ammonium acetate show different charge state distributions (CSD) (Figure 3). The highest average charge states were observed for the solutions with the lowest ionic strength. This phenomenon was previously reported for oligonucleotide in the negative mode $[44,45]$. Moreover, the charge state distributions at $15 \mathrm{mM} \mathrm{NH} 4 \mathrm{OAc}$ are bimodal, independently of whether we have an i-motif or a random coil structure in solution.

For proteins, bimodal CSD are usually interpreted as due to the coexistence of two structural ensembles in solution [25, 27]: a low-charge state distribution corresponding to the folded ensemble, and a high-charge state distribution corresponding to the unfolded ensemble. This is not what we observe with our nucleic acids. Here, the CSDs of fully folded i-motif and random coil structures show the same behavior at each concentration of ammonium acetate. However, the $\mathrm{NH}_{4} \mathrm{OAc}$ concentration has the greatest influence on the CSDs, despite the solution structures are unchanged (see NMR data). In particular, the bimodal charge distribution appears only at low $(15 \mathrm{mM}) \mathrm{NH}_{4} \mathrm{OAc}$ concentration. ESI-MS spectra for $50 \mathrm{mM}$ $\mathrm{NH}_{4} \mathrm{OAc}$ and higher presented a narrow CSD (ion with 4- to 6- charges). The traditional interpretation of charge state distributions in terms of solution folding would lead to erroneous conclusions regarding the nucleic acid folding status in solution. 
A

i-motif

21C at pH 5.5

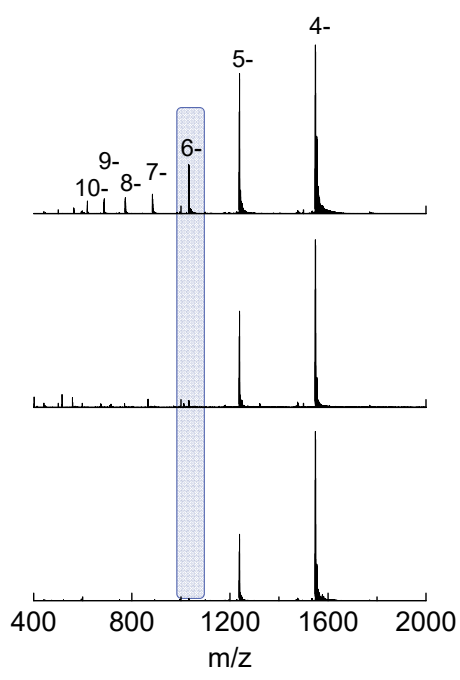

B

Controls (random coil)

21C at $\mathrm{pH} 7.5$

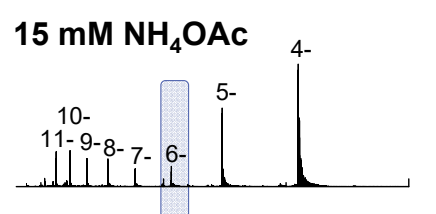

$50 \mathrm{mM} \mathrm{NH}_{4} \mathrm{OAC}$
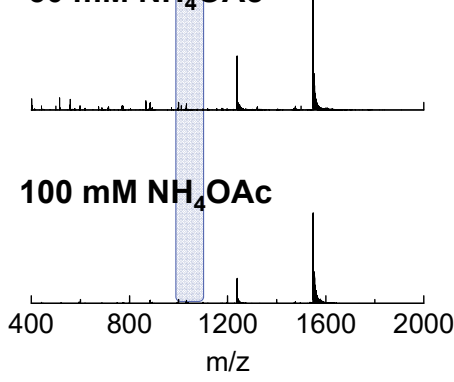

C

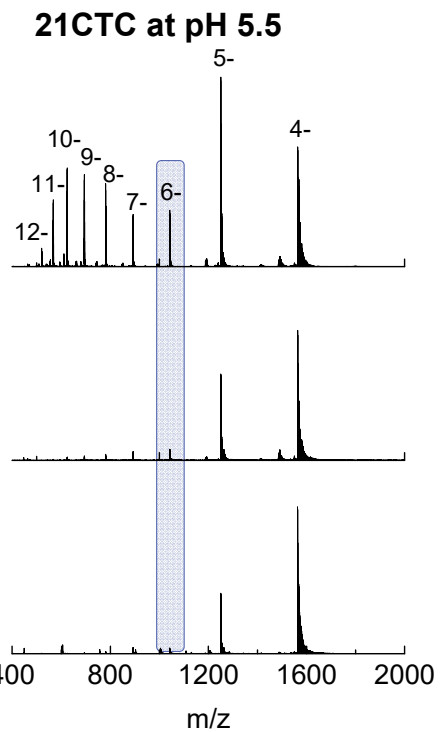

Figure 3. Mass spectra acquired for folded i-motif $21 \mathrm{C}$ at pH $5.5(\boldsymbol{A})$ and its controls $21 \mathrm{C}$ at pH 7.5 (B) and 21CTC at pH 5.5 (C) in 15, 50 and $100 \mathrm{mM} \mathrm{NH} 4 \mathrm{OAc}$. The data for 21CTC at $\mathrm{pH}=7.5$ are shown in Supplementary Figure $\boldsymbol{S} 2$. 


\section{Ion mobility spectrometry of the 21-mer i-motif and its controls}

The ions with the lowest charge states (4- and 5-) have CCS values below $700 \AA^{2}$ (Figure 4), indicative of a compact structure, whatever the solution folding state. On close inspection, a very slight shift is observable between folded $21 \mathrm{C}(\mathrm{pH}=5.5)$ and unfolded $21 \mathrm{C}(\mathrm{pH}=7.5)$

(Table 1), but the relative shift in the peak maximum is only of $1.5 \%$ for the 4 - ions and $2.5 \%$ for the 5- ions. The CCS values of ions with 4- and 5- charge states do not show significant changes with the $\mathrm{NH}_{4} \mathrm{OAc}$ concentration (Table 1). Similarly, the CCS values of the 4- and 5- ions of $21 \mathrm{CTC}$ at $\mathrm{pH} 5.5$ were similar at all $\mathrm{NH}_{4} \mathrm{OAc}$ concentrations.

Ions with 7- and 11- charge states all have CCS values $\geq 1000 \AA^{2}$, independently of the solution conformations (Figure 4 and Table 1). Presumably, this charge density disrupts most intramolecular interactions, native and non-native ones alike. As a result, the DNA structures get elongated. However, the presence of highly charged ions strongly depends on initial solution ionic strength: high charge states are mostly produced at lower $\mathrm{NH}_{4} \mathrm{OAc}$ concentration.

Finally, the intermediate charge state 6- showed the greatest sensitivity to solution folding. When the i-motif is formed in solution, the CCS distribution shows a single peak at $714 \pm 3$ $\AA^{2}$ (mean value over all $\mathrm{NH}_{4} \mathrm{OAc}$ concentrations and standard error on the estimate of the mean). For all controls, the CCS is larger and the CCS distribution shows multiple peaks. However, the CCS profile of the unfolded structure is very sensitive to the $\mathrm{NH}_{4} \mathrm{OAc}$ concentration, even though the solution NMR spectra are the same: at $15 \mathrm{mM} \mathrm{NH}_{4} \mathrm{OAc}$, the 6- ion conformations are more compact; at $100 \mathrm{mM} \mathrm{NH} 4 \mathrm{OAc}$, only an extended form (CCS = $897 \AA^{2}$ ) is observed. Note that the previous study Fernandez-Lima and collaborators [34], who found no marked effect of the $\mathrm{pH}$ on the ion mobility of $21 \mathrm{C}$, had been carried out in 10 $\mathrm{mM} \mathrm{NH} 4 \mathrm{OAc}$, so our results are consistent with theirs. 
A

i-motif

21C at pH 5.5
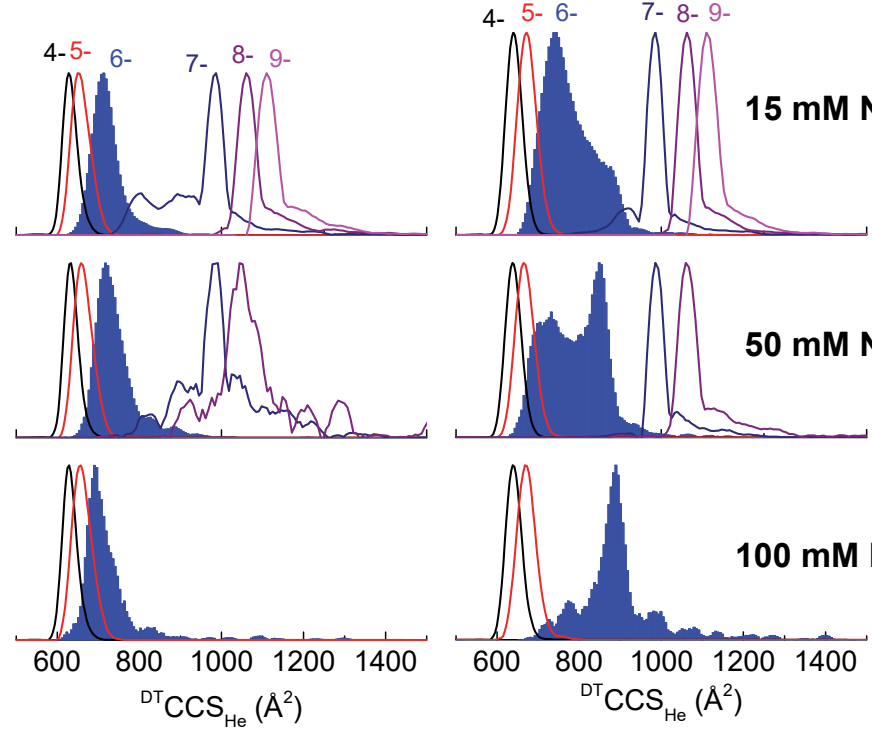

21C at pH 7.5

$$
\text { 4- 5- 6- 7- 8- 9- }
$$

B

Controls (random coil)

C

\section{$21 \mathrm{CTC}$ at $\mathrm{pH} 5.5$}
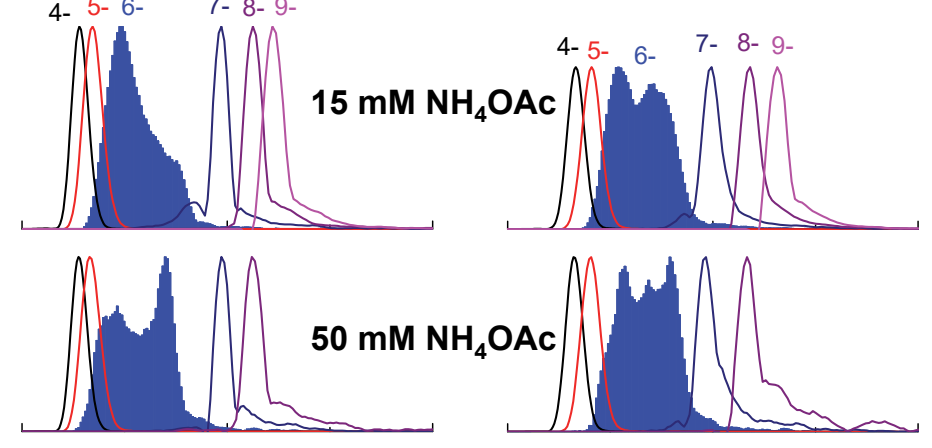

Figure 4. CCS distributions for ions with different charge states of folded i-motif $21 \mathrm{C}$ at $\mathrm{pH}$ $5.5(\boldsymbol{A})$ and its controls $21 \mathrm{C}$ at $\mathrm{pH} 7.5(\boldsymbol{B})$ and $21 \mathrm{CTC}$ at pH $5.5(\boldsymbol{C})$ in 15,50 and $100 \mathrm{mM}$ $\mathrm{NH}_{4} \mathrm{OAc}$. All distributions are scaled to 1 for visualization of the least abundant charge states. The data for $21 \mathrm{CTC}$ at $\mathrm{pH}=7.5$ are shown in Supplementary Figure S2. 
Table 1. Helium collision cross sections $\left({ }^{D T} C C S_{H e}\right.$, in $\left.A^{2}\right)$ at $23.5^{\circ} \mathrm{C}$ for the sequence $21 \mathrm{C}$ $\left(d(C C C T A A)_{3} C C C\right)$ in different solution conditions, at different charge states. When standard deviation is provided, $\mathrm{N}=3$ (except for $21 \mathrm{C}$ (6-) $50 \mathrm{mM} \mathrm{pH} 5.5 \mathrm{~N}=5$ ).

\begin{tabular}{|c|c|c|c|c|c|c|c|}
\hline \multicolumn{2}{|c|}{ Solution conditions } & $\begin{array}{l}\text { CCS } \\
(4-) / \\
\AA^{2}\end{array}$ & $\begin{array}{l}\text { CCS } \\
(5-) / \\
\AA^{2}\end{array}$ & $\begin{array}{l}\operatorname{CCS}(6-) / \\
\AA^{2}\end{array}$ & $\begin{array}{l}\text { CCS } \\
(7-) / \\
\AA^{2}\end{array}$ & $\begin{array}{l}\text { CCS } \\
(8-) / \\
\AA^{2}\end{array}$ & $\begin{array}{l}\text { CCS } \\
(9-) / \\
\AA^{2}\end{array}$ \\
\hline \multirow{2}{*}{$\begin{array}{l}{\left[\mathrm{NH}_{4} \mathrm{OAc}\right]} \\
=15 \mathrm{mM}\end{array}$} & $\begin{array}{l}\mathrm{pH}=5.5 \\
\text { (folded) }\end{array}$ & $\begin{array}{l}631.5 \\
\pm 3.3\end{array}$ & $\begin{array}{l}653.9 \\
\pm 2.7\end{array}$ & $717 \pm 6$ & 984 & 1061 & 1111 \\
\hline & $\begin{array}{l}\mathrm{pH}=7.5 \\
\text { (not folded) }\end{array}$ & $\begin{array}{l}640.9 \\
\pm 0.5\end{array}$ & $\begin{array}{l}671.1 \\
\pm 1.3\end{array}$ & $\begin{array}{l}740 \pm 4 \\
\text { (first peak) }\end{array}$ & 984 & 1063 & 1111 \\
\hline \multirow{2}{*}{$\begin{array}{l}{\left[\mathrm{NH}_{4} \mathrm{OAc}\right]} \\
=50 \mathrm{mM}\end{array}$} & $\begin{array}{l}\mathrm{pH}=5.5 \\
\text { (folded) }\end{array}$ & $\begin{array}{l}630.3 \\
\pm 1.6\end{array}$ & $\begin{array}{l}654.4 \\
\pm 2.9\end{array}$ & $717 \pm 5$ & 983 & 1042 & 1106 \\
\hline & $\begin{array}{l}\mathrm{pH}=7.5 \\
\text { (not folded) }\end{array}$ & $\begin{array}{l}638.9 \\
\pm 0.9\end{array}$ & $\begin{array}{l}668.5 \\
\pm 4.7\end{array}$ & $\begin{array}{l}733 \pm 26 \\
\text { (first peak) }\end{array}$ & 987 & 1062 & 1108 \\
\hline \multirow{2}{*}{$\begin{array}{l}{\left[\mathrm{NH}_{4} \mathrm{OAc}\right]} \\
=100 \mathrm{mM}\end{array}$} & $\begin{array}{l}\mathrm{pH}=5.5 \\
\text { (folded) }\end{array}$ & $\begin{array}{l}631.2 \\
\pm 2.8 /\end{array}$ & $\begin{array}{l}655.5 \\
\pm 2.9 /\end{array}$ & $\begin{array}{l}705 \pm 12 \\
\text { (almost no } \\
\text { signal) }\end{array}$ & $\begin{array}{l}\text { No } \\
\text { signal }\end{array}$ & $\begin{array}{l}\text { No } \\
\text { signal }\end{array}$ & $\begin{array}{l}\text { No } \\
\text { signal }\end{array}$ \\
\hline & $\begin{array}{l}\mathrm{pH}=7.5 \\
\text { (not folded) }\end{array}$ & $\begin{array}{l}641.9 \\
\pm 2.5\end{array}$ & $\begin{array}{l}673.5 \\
\pm 2.5\end{array}$ & $\begin{array}{l}897 \pm 7 \\
\text { (main } \\
\text { peak) }\end{array}$ & 987 & 1074 & $\begin{array}{l}\text { No } \\
\text { signal }\end{array}$ \\
\hline
\end{tabular}




\section{Effect of pre-IMS ion activation}

\section{1-mers}

The 6- charge state of the 21-mers, which is the most sensitive to solution folding and to solution conditions ( $\mathrm{NH}_{4} \mathrm{OAc}$ concentration), is also remarkably sensitive to collisional activation prior to IMS. The collision-induced unfolding (CIU) upon increasing the trap entrance grid delta (TEGD) voltage can be visualized in Figure 5 for the 6- charge state, and in Supplementary Figure $\mathbf{S 3}$ for charge states 5- and 7- of 21C.

The CIU profile of the i-motif structure $(\mathrm{pH}=5.5)$ is similar for all $\mathrm{NH}_{4} \mathrm{OAc}$ concentrations (although the signal is higher at low $\mathrm{NH}_{4} \mathrm{OAc}$ concentration), and shows a transition around TEGD $=7 \mathrm{~V}$ (Figure 5A-C). In contrast, the CIU profile of the random coil controls varies significantly with the $\mathrm{NH}_{4} \mathrm{OAc}$ concentration. First, the profile reflects the different fraction of compact/extended structures at the start $(\mathrm{TEGD}=1 \mathrm{~V})$, which varies with the $\mathrm{NH}_{4} \mathrm{OAc}$ concentration (Figure 5D-I). At $15 \mathrm{mM} \mathrm{NH}_{4} \mathrm{OAc}$ the compact conformation predominates, and unfolds around TEGD $=5 \mathrm{~V}$ (Figure 5D). Thus, this compact conformation is not the same as a folded i-motif, and we propose that these compact structures result from a nonspecific compaction upon electrospray, with weaker intramolecular interactions than the pre-folded i-motif.

The control DNA sequences $21 \mathrm{C}$ at $\mathrm{pH}=7.5$ in $50 \mathrm{mM} \mathrm{NH}_{4} \mathrm{OAc}$ and $21 \mathrm{CTC}$ at $\mathrm{pH}=5.5$ in 15 or $50 \mathrm{mM} \mathrm{NH}_{4} \mathrm{OAc}$ present the wide variety of conformations, with $\mathrm{CCS}_{\mathrm{He}}$ values from 700 to $900 \AA^{2}$, at TEGD up to $5 \mathrm{~V}$, and final extension at TEGD $\geq 5 \mathrm{~V}$ (Figure $5 \boldsymbol{E}, \boldsymbol{G}, \boldsymbol{H}$ ). Finally, only the extended conformation $\left(\mathrm{CCS}_{\mathrm{He}}=897 \AA^{2}\right)$ is present when random coils are sprayed from $100 \mathrm{mM} \mathrm{NH} 4 \mathrm{OAc}$, independently of the pre-IMS activation (Figure $\mathbf{5 F}, \boldsymbol{I}$ ).

In summary, the CIU profiles can highlight the differences between folded and unfolded structures, but a caveat is that the CIU profiles of the solution random coils markedly depend on the $\mathrm{NH}_{4} \mathrm{OAc}$ concentration. At low $\mathrm{NH}_{4} \mathrm{OAc}$ concentration, the shape of the CIU plot of the random coil could be easily mistaken for one of a folded i-motif of lesser stability. 

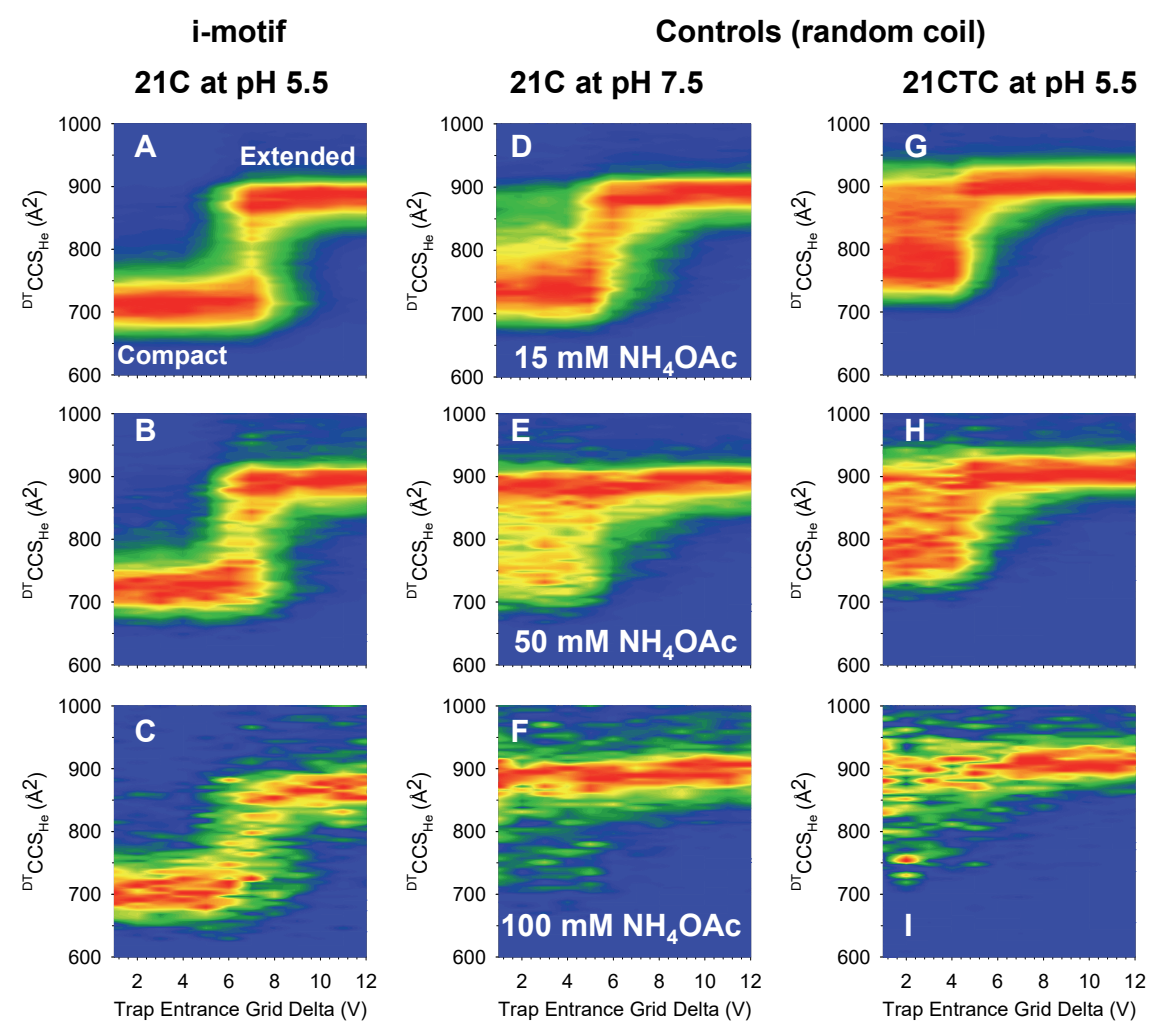

Figure 5. Heatmap reconstructions showing the collisional induced unfolding (CIU) for charge states 6- of i-motif structures $21 \mathrm{C}$ at pH $5.5(\boldsymbol{A}, \boldsymbol{B}, \boldsymbol{C})$ and its controls $21 \mathrm{C}$ at pH 7.5 $(\boldsymbol{D}, \boldsymbol{E}, \boldsymbol{F})$ and $21 \mathrm{CTC}$ at $\mathrm{pH} 5.5(\boldsymbol{G}, \boldsymbol{H}, \boldsymbol{I})$ in 15,50 and $100 \mathrm{mM}$ of $\mathrm{NH}_{4} \mathrm{OAc}$ (top to bottom). The data for 21CTC at $\mathrm{pH}=7.5$ are shown in Supplementary Figure S2.

\section{0-mers}

To see if these observations hold for longer sequences, we studied the 30 -mer analogues $30 \mathrm{C}$ $(\mathrm{d}(\mathrm{TAACCC}) 5)$ and $30 \mathrm{CTC}(\mathrm{d}(\mathrm{TAACTC}) 5)$. In solution at $\mathrm{pH}=5.7,30 \mathrm{C}$ forms an i-motif structure and 30CTC a random coil, according to $\mathrm{CD}$ and melting experiments (Supplementary Figure S4). The mass spectra, CCS distributions at low collision energy, and CIU profiles for charge state 8- are shown in Figure 6, and the CCS values are given in

Table 2. Again, the charge state distribution becomes bimodal at low $\mathrm{NH}_{4} \mathrm{OAc}$ concentration. The CCS distributions show a series of charge states with compact conformations (5-, 6- and $7-,<1000 \AA^{2}$ ), a series of charge states with extended conformations (charge states 10- and higher, $\left.\left.>1400 \AA^{2}\right)\right)$, and charge states that lie in between $\left(8-, 9-\right.$ and, at $\left[\mathrm{NH}_{4} \mathrm{OAc}\right]=100$ $\mathrm{mM}, 7-)$. 
Interestingly, like the 6- charge state of the 21-mers, these charge states are those lying at the intersection of the bimodal charge state distribution of low $\mathrm{NH}_{4} \mathrm{OAc}$ concentration and again, the conformations ending up under these charge states depends on the $\mathrm{NH}_{4} \mathrm{OAc}$ concentration. Finally, these three charge states were also the most sensitive to collisioninduced unfolding (see Figure 6 for 8-, Supplementary Figure S5 for 7-). Thus, the most analytically useful charge states on the point of view of CIU are also those giving the most puzzling behavior with regard to their sensitivity to electrolyte concentration in addition to solution pre-folding. Also, these charge states have a very low abundance at physiological ionic strength (which would correspond to $\left[\mathrm{NH}_{4} \mathrm{OAc}\right]=150 \mathrm{mM}$ ).

Table 2. ${ }^{D T} \mathrm{CCS} \mathrm{He}_{\mathrm{He}}$ at $23.5^{\circ} \mathrm{C}$ values calculated for different charge states of $i$-motif (30C at

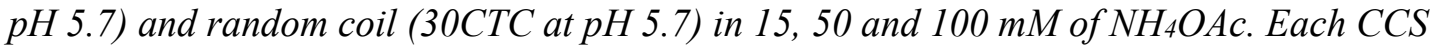
value was calculated on a single sample.

\begin{tabular}{|c|c|c|c|c|c|c|c|}
\hline$\left[\mathrm{NH}_{4} \mathrm{OAc}\right]$ & \begin{tabular}{|c|}
$\begin{array}{c}\text { Sequence } \\
\text { (structure in } \\
\text { solution) }\end{array}$ \\
\end{tabular} & $\begin{array}{c}\mathrm{CCS} \\
(5-) / \\
\AA^{2}\end{array}$ & $\begin{array}{c}\text { CCS } \\
(6-) / \\
\AA^{2}\end{array}$ & $\begin{array}{c}\mathrm{CCS} \\
(7-) / \\
\AA^{2}\end{array}$ & $\begin{array}{c}\mathrm{CCS} \\
(8-) / \\
\AA^{2}\end{array}$ & $\begin{array}{c}\text { CCS } \\
(9-) / \\
\AA^{2}\end{array}$ & $\begin{array}{c}\text { CCS } \\
(10-) / \\
\AA^{2}\end{array}$ \\
\hline \multirow{2}{*}{$15 \mathrm{mM}$} & $\begin{array}{c}30 \mathrm{C} \\
\text { (i-motif) }\end{array}$ & 819 & 851 & 904 & 1013 & 1165 & 1217 \\
\hline & $\begin{array}{c}30 \mathrm{CTC} \\
\text { (unstructured) }\end{array}$ & 846 & 882 & 939 & 1145 & 1398 & 1506 \\
\hline \multirow{2}{*}{$50 \mathrm{mM}$} & $\begin{array}{c}30 \mathrm{C} \\
\text { (i-motif) }\end{array}$ & 820 & 850 & 907 & 1009 & 1145 & $\begin{array}{c}\text { No } \\
\text { Signal }\end{array}$ \\
\hline & \begin{tabular}{|c|}
$30 \mathrm{CTC}$ \\
(unstructured)
\end{tabular} & 842 & 883 & 928 & 1275 & 1393 & 1504 \\
\hline \multirow{2}{*}{$100 \mathrm{mM}$} & $\begin{array}{c}30 \mathrm{C} \\
\text { (i-motif) }\end{array}$ & 820 & 853 & 874 & $\begin{array}{c}\text { No } \\
\text { Signal }\end{array}$ & $\begin{array}{c}\text { No } \\
\text { Signal }\end{array}$ & $\begin{array}{c}\text { No } \\
\text { Signal }\end{array}$ \\
\hline & $\mid \begin{array}{c}30 \mathrm{CTC} \\
\text { (unstructured) }\end{array}$ & 844 & 886 & 1111 & 1276 & 1404 & 1521 \\
\hline
\end{tabular}




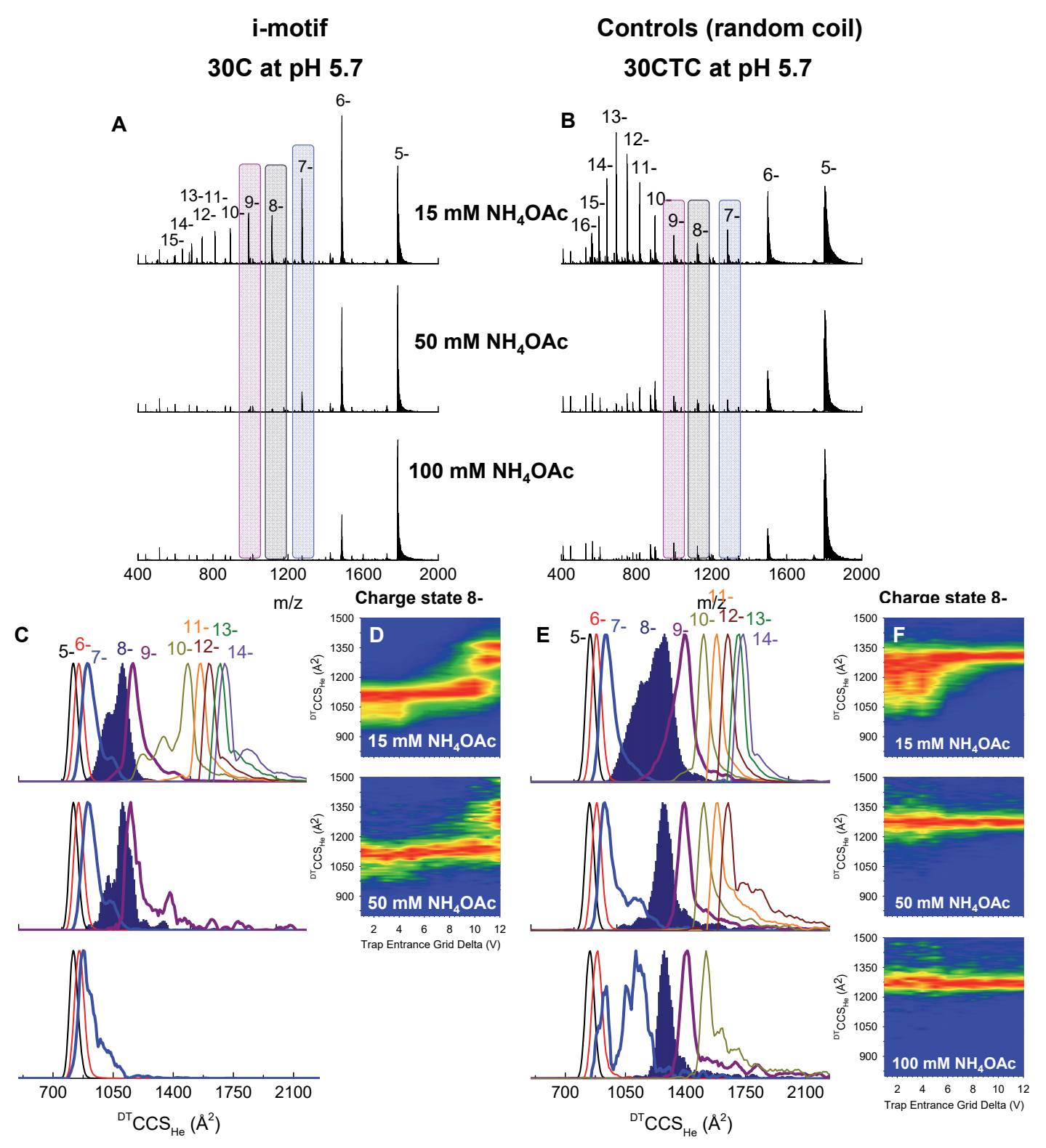

Figure 6. Mass spectra acquired for folded i-motif 30C (A) and its control 30CTC (B) at pH 5.5 in 15, 50 and $100 \mathrm{mM}$ of $\mathrm{NH}_{4} \mathrm{OAc}$. The CCS distributions for ions with different charge states of $30 \mathrm{C}(\boldsymbol{C})$ and $30 \mathrm{CTC}$ at $\mathrm{pH} 7.5(\boldsymbol{E})$ in 15,50 and $100 \mathrm{mM}$ of $\mathrm{NH}_{4} \mathrm{OAc}$. The heatmaps show the collisional induced unfolding (CIU) for charge states 8- of i-motif structures 30C (D) and its control 30CTC (F) at pH 5.5 in 15, 50 and $100 \mathrm{mM}$ of $\mathrm{NH}_{4} \mathrm{OAc}$. 


\section{Discussion}

\section{Non-folded DNA solution structures become compact in the gas phase at the main charge states produced from "native" conditions}

All spectroscopy results demonstrate an that i-motif structure is formed by $21 \mathrm{C}$ at $\mathrm{pH} 5.5$ in solutions with 15, 50 and $100 \mathrm{mM} \mathrm{NH}_{4} \mathrm{OAc}$ at room temperature, and that there is no i-motif for $21 \mathrm{C}$ at $\mathrm{pH} 7.5$ or with the control sequence, whatever the $\mathrm{NH}_{4} \mathrm{OAc}$ concentration. So, compaction of random coils observed in the ion mobility data is not coming from solution pre-folding. We investigated several possible scenarios that could explain the compactness of gas-phase ion structures produced from the random coils at low ionic strength.

"Unstructured" does not necessarily mean "extended". Could random coil structures exhibit a compact conformation in solution? Ren et al. recently investigated the hydrodynamic radius of folded and unfolded $21 \mathrm{C}$ analogue at different ionic strengths $(0-100 \mathrm{mM} \mathrm{NaCl})$ and $\mathrm{pH}$ values, using fluorescence correlation spectroscopy [46]. They found a hydrodynamic radius of $1.8 \mathrm{~nm}$ for the folded i-motif $(\mathrm{pH}=5.5)$ and of $2.2 \mathrm{~nm}$ for the random coil $(\mathrm{pH}=7.5)$, independently of the ionic strength. Converting radii to surface areas would translate into a CCS change of $+50 \%$ in the random coils compared to the i-motifs. The gas-phase CCS values are much closer than that, and depend on the ionic strength, so the gas-phase compactness of random coil structures is not explained by their compactness in solution. Compaction occurs upon electrospray.

Second, could the $\mathrm{pH}$ of droplets change significantly and induce i-motif formation from the random coil structures during ESI process? The Cook and Dugourd groups demonstrated that indeed the pre-sprayed $\mathrm{pH}$ value changes during ESI process $[47,48]$, but in negative ion mode, droplets initially at $\mathrm{pH}=7.5$ undergo an increase in their $\mathrm{pH}$, up to 8.0. This would further disfavor i-motif formation. We also calculated that, at $\mathrm{pH}$ values between 5.5 and 7.5, ammonium acetate was always mostly in the ionic forms $\mathrm{OAc}^{-}$and $\mathrm{NH}_{4}{ }^{+}$(at most, there is $16 \% \mathrm{HOAc}$ at $\mathrm{pH}=5.5$, and $2 \% \mathrm{NH}_{3}$ at $\mathrm{pH}=7.5$ ). Besides, compaction was seen at $\mathrm{pH}=5.5$ for the control sequences unable to form i-motifs.

Thus, compaction must occur elsewhere than in the droplet's bulk. For the lowest charge states (4- and 5- for the 21-mers, 5- to 7-for the 30-mers), compaction may occur in the gas phase because, if the Coulomb repulsion is low enough, forming new nonspecific noncovalent interactions can be energetically favorable. Pre-IMS activation fails to extend the 
conformations at these charge states. We observed this phenomenon previously for DNA and RNA duplexes, at the main charge states produced from $100 \mathrm{mM}$ or $150 \mathrm{mM} \mathrm{NH} 4 \mathrm{OAc}$ [32]. G-quadruplexes of low charge states (5- for 22-mers) can also get more compact upon activation [49]. Lower CCS values for lower charge states of single strand (sprayed from water, $70 \%$ methanol and $1 \%$ trimethylamine) were also reported recently [50]. However, for the charge states that are sensitive to CIU, the energetically most favored conformation is the extended one, and thus the compact conformations must have been kinetically trapped following the electrospray process. In summary, if such compact structures can be formed neither in the bulk, nor in the gas phase, it means that they must result from processes occurring in the "intermediate regime" [51] of electrospray droplets, i.e. at the charged water/air interface.

\section{How to spot the differences between specifically folded gas-phase structures and nonspecifically compacted gas-phase structures}

First, differences can only be spotted when working with the least energetic pre-IMS conditions. The optimization of all parameters for softness was particularly crucial for the smallest system (21-mer): with the default instrument tuning, we would have found all the 6ions extended (right part of the CIU plot). For larger systems, the number of charge states increases, and thus the chances of finding one that will be discriminatory will increase. Second, even in soft conditions, the differences in CCS are extremely small (as low as $1 \%$ for the lowest charge states), and can only be evidenced by carrying a control experiment in solution conditions that affect the folding, for example here by changing the $\mathrm{pH}$. Note however that varying the ionic strength is not a good option to alter the solution folding for control experiments, because the electrolyte concentration largely affects the CCS via other electrospray-related phenomena discussed below.

Recording the entire CIU profile helps spotting differences: although the low-energy CCS profile can be similar at some charge states and $\mathrm{NH}_{4} \mathrm{OAc}$ concentrations, and although the high-energy profile may be the same, the collision energy at which unfolding occurs reflects the strength of intramolecular non-covalent bonds present following electrospray. However, this can be revealed only for a limited range of charge states, high enough for Coulomb repulsion to cause significant CCS increase, but not too high, otherwise all relevant intramolecular interactions would be disrupted already at the lowest energies. Annoyingly, the most interesting charge states for CIU are the least abundant of the charge state 
distributions, and they are almost not present at physiological ionic strength, mimicked at $\left[\mathrm{NH}_{4} \mathrm{OAc}\right] \approx 150 \mathrm{mM}$.

\section{The $\mathrm{NH}_{4} \mathrm{OAc}$ concentration affects the gas-phase ion structures through its influence on the electrospray charging pathways}

The observations we need to explain are summarized as follows:

- Bimodal charge distributions can be obtained even when the DNA in solution is fully unstructured, and thus the charge state distribution cannot be used to infer solution folding/unfolding fractions of DNA.

- At high electrolyte concentrations, the fraction of the high-charge state distribution decreases, and the average charge state of each distribution decreases. At 50 or $100 \mathrm{mM}$ $\mathrm{NH}_{4} \mathrm{OAc}$, it is not possible to differentiate folded and unfolded structures based on the charge state distribution.

- At low electrolyte concentrations, the fraction of the high-charge state distribution increases. Although it increases less for the folded structures than for the unfolded ones, it is not possible to recommend an electrolyte concentration at which the charge state distribution would convey quantitative information on the folded/unfolded fractions in solution.

- The non-folded DNA solution structures that end up in the low charge state distribution are nearly as compact in the gas phase as initially folded structures.

- The "critical" charge state(s) where Coulomb repulsion almost balances intramolecular interactions is both the most sensitive to internal energy changes (collision-induced unfolding) and the most sensitive to electrospray effects (electrospray-induced unfolding or electrospray-induced compaction).

- The electrolyte concentration influences the fraction of compact/extended conformations ending up under these critical charge states: at low electrolyte concentrations, the fraction of compact conformation under these critical charge states increases. 
We interpret these results in light of a partitioning of the analytes between two electrospray pathways, understood here as limiting cases: a charged residue pathway (CRM), wherein the analyte ions stay in the droplet interior until the last moment, and a chain ejection pathway (CEM), wherein the analyte ions migrate to the surface of the charged droplets, where they can change conformation and then lose contact with the droplet (Figure 7). The fraction of the analytes undergoing CRM vs. CEM depends on:

(1) The folding state in solution. Folded structures are generally thought to take the CRM pathway. This is likely to be valid for nucleic acids as well: nucleobases are more hydrophobic than the sugar-phosphate backbone, and thus base pairing and stacking buries hydrophobic groups while hydrophilic groups are in contact with the solvent. Counterions in solution (here: $\mathrm{NH}_{4}{ }^{+}$) partially neutralize the phosphate groups [52], and thus the final charges state are much lower than the number of phosphate groups.

(2) The concentration of electrolyte. Electrolytes and analytes compete for the excess charges on the surface of the electrospray droplets $[53,54]$. If the electrolyte concentration is high enough, analytes that are not particularly surface-active will stay in the bulk of the droplets, and will thus be more likely to take the CRM pathway. However, if the electrolyte concentration is decreased, the electrolyte may not be present in sufficient amounts to provide all the excess charges on the surface of the droplets, and ionic analytes will contribute populating the droplet surface. As a result, a higher fraction of analytes may end up taking the CEM pathway. We currently don't know how the cations partition between the center and the surface of negative droplets, and thus how phosphatecation interactions is affected at the droplet surface or at the droplet/air interface. We however presume that cation concentration close to the negative surface the droplets is lower than in the bulk, and that for this reason higher charge states are produced by the CEM (fewer phosphate groups neutralized). The folding state in solution also influences the probability to take the CEM pathway, as exposure of hydrophobic residues may enhance surface activity. Yet our results show that, for nucleic acids, the folding state in solution has a lesser influence than the electrolyte concentration. 


\section{Low electrolyte concentration}

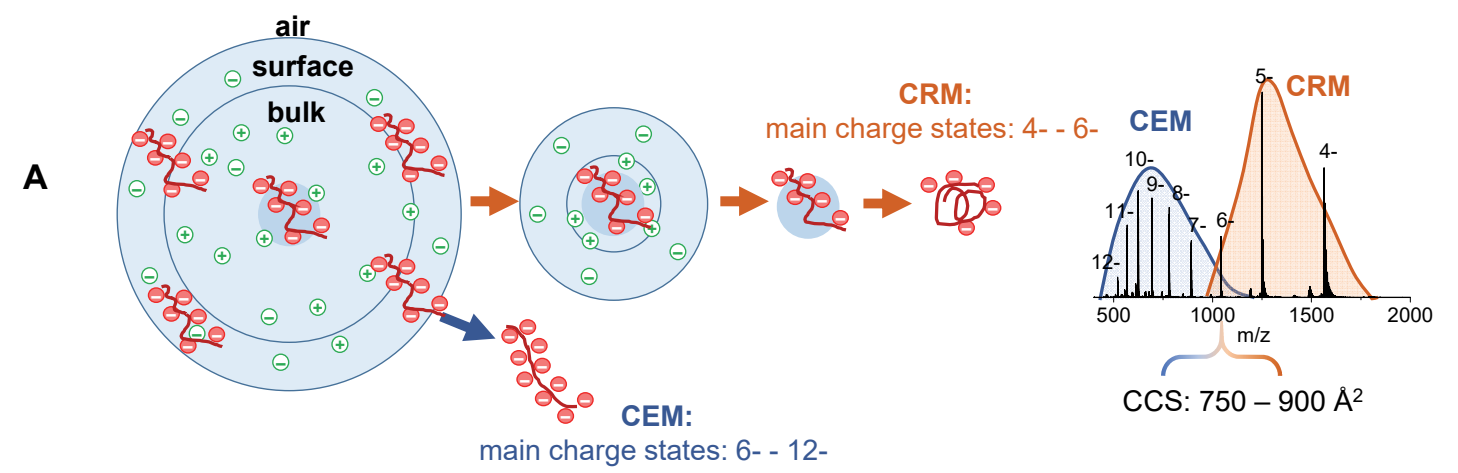

High electrolyte concentration

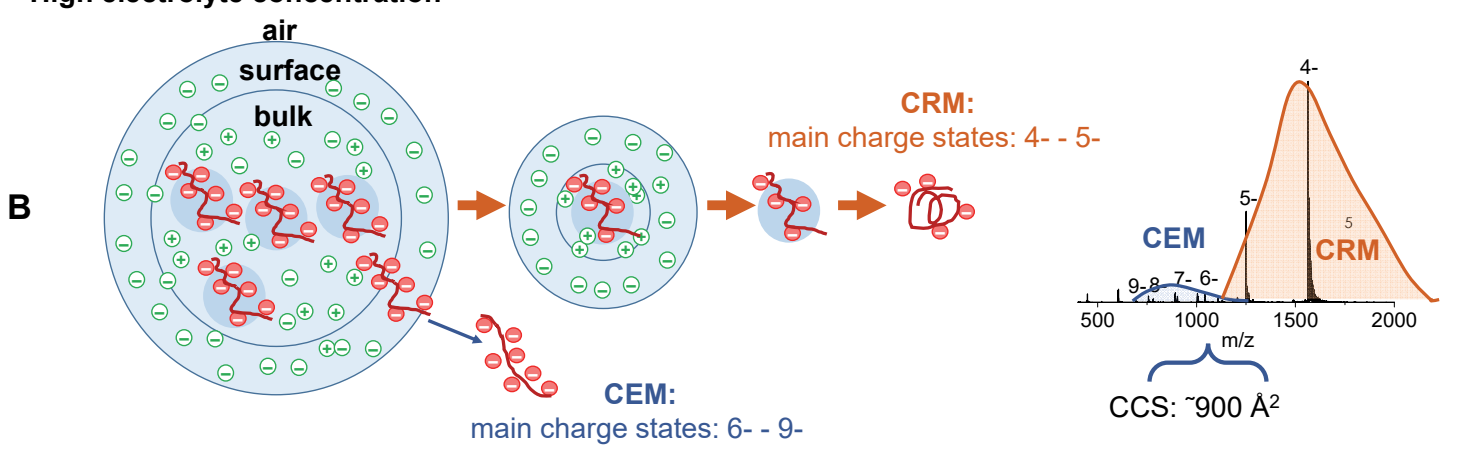

Figure 7. Electrospray ionization of unfolded DNA: illustration of the partitioning between the CRM and CEM pathways at different electrolyte concentrations, which affects the resulting charge state distributions and the population ending up under the critical charge states in-between the two distributions. The mass spectra are those of $21 \mathrm{CTC}$ at $\mathrm{pH}=5.5$ (random coil). (A) When the sprayed solution contains low electrolyte concentration, lack of electrolyte charge carriers on the droplet surface is partially compensated by the negatively charged DNA. In turn, the presence of charged DNA on the droplet surface makes the ionization via a chain ejection model (CEM) more probable. Another fraction of DNA, remaining in the bulk, is ionized via the charged residue (CRM) pathway. (B) When the sprayed solution contains high electrolyte concentration, the charge density on the droplet surface is mostly provided by electrolyte, and the DNA has a lesser tendency to reach the surface and to be ionized by the CEM pathway. The major fraction of DNA remains in the bulk and is ionized via CRM. Both charge state distributions shift to lower values when the electrolyte concentration increases. As a consequence, under the critical charge state 6-, the fraction of ions having undergone CEM (extended) is larger when sprayed from high electrolyte concentrations, and the fraction of ions having undergone the CRM (compact) is larger when sprayed from low electrolyte concentrations. 


\section{Electrolyte concentration effects: nucleic acids vs. proteins}

Given that these mechanisms should be general, why are electrospray effects (electrolyte concentration effects) so prominent for nucleic acids, but remained under the radar for proteins? The main difference lies in the nature of the charge carriers. Nucleic acids carry multiple negative charges in solution, at each phosphate group. They can thus serve as excess charge carriers on the surface of electrospray droplets in the negative mode. If a nucleic acid is close to the surface when the droplet fissions, it will be entrained in the "intermediate regime" of electrospray [51], a highly charged solvated environment in which it can change conformation, unfold, and extend if the Coulomb repulsion is high enough. This intermediate regime may be close to the chain ejection model (CEM) [55]. Note that in positive mode, nucleic acids can never carry as many charges as in the negative mode [34], even in the presence of supercharging additives [45]. The explanation is that they have no reason to sit on the surface of a positively charged droplet and thus no chance to undergo CEM.

In bulk solution, the phosphate groups are partially neutralized by electrolyte cations, and the extent of neutralization depends on the ionic strength. Some folding motifs can involve cation or proton binding to the bases, but nucleic acids still carry a net negative charge. Folding can thus reduce the propensity to undergo CEM, but not totally prevent it if the electrolyte concentration is low enough. This is why a fraction of the i-motif $(\mathrm{pH}=5.5)$ ends up taking high charges in $15 \mathrm{mM} \mathrm{NH} 4 \mathrm{OAc}$. Conversely, having an unfolded nucleic acid structure in solution is not sufficient to ensure that ionization occurs through the CEM pathway, and thus gain high charges and extended conformations. Unfolded nucleic acids indeed remain very hydrophilic because the phosphate groups are distributed all along the backbone, and they would thus tend to stay in the droplet center rather than at the surface if possible. Unfolded structures thus also undergo CRM, and by doing so they attain low charge states and can even undergo gas-phase compaction by forming new non-native hydrogen bonds.

Proteins, in contrast, usually have a clearer partitioning between the CRM and CEM pathway, depending on whether they are folded or unfolded in aqueous solution. Unfolded proteins usually expose many hydrophobic residues to the solvent. This increases their surface activity, and thus their propensity to take the CEM pathway. Folded proteins, on the other hand, bury hydrophobic residues in their center and display hydrophilic ones on their solvent accessible surface area, and are thus more likely to undergo the CRM. When the ionic strength decreases, for most proteins the partitioning does not change, because they have both 
acidic and basic residues, and the counter-ion effects of the electrolytes apply to both. However, very acidic proteins behave like nucleic acids: when sprayed at low ionic strength in negative mode, folded acidic proteins take up many charges, and this results in gas-phase unfolding [56].

In summary, the same principles of analyte partitioning between the CRM and CEM pathways apply to nucleic acids and proteins alike, but because the nature and relative strength of the noncovalent interaction forces and the distribution of the charge carriers differ, the typically observed outcome differs.

\section{Conclusion}

By studying nucleic acids, which have different distributions of charge carriers on their backbone than proteins, we reveal some general features of electrospray mechanisms, which influence the interpretation of ion mobility data for native mass spectrometry. The gas-phase conformations are intimately tied to the electrospray charging mechanism, and the charging mechanism is itself intimately tied to the solution structure (the folding status and the nature of the exposed residues). Whether folded or non-folded structures in solution end up at low or high charge states depends on the nature of the charge carriers and on the competition with electrolytes to serve as excess charge carriers in the electrospray droplets. This process can be understood in the framework of a partitioning of the analyte between the droplet bulk and the droplet surface, which then influences the probability that the analyte is ionized via the charged residue mechanism (CRM) or the chain ejection mechanism (CEM), respectively. In turn, whether biomolecules at each charge state end up compact or extended in the gas phase depends on the balance between Coulomb repulsion and intramolecular forces, and on how much internal energy was provided to overcome rearrangement barriers.

Our study highlights the importance of control experiments to interpret ion mobility results to assign whether a biomolecule was initially folded or unfolded in solution. The controls include studying the dependence of ion mobility spectra on the activation conditions, and carrying out experiments with mutant sequences, ideally of the same size, having a known folding status in solution. However, before ascribing the effects of solution parameters (electrolyte concentration, $\mathrm{pH}$, presence of additives,...) to an effect on the solution folding status, it is important to check the extent to which these solution parameters may also 
influence the electrospray charging process. When bimodal distributions are observed in native MS, it does not always mean that two conformational ensembles are present in solution. Varying the electrolyte concentration is a useful test to check the possibility of a competition between different electrospray charging mechanisms, before interpreting the results in terms of solution conformations. Much remains to be learned, however, on the partitioning of cations, anions, and neutral co-solutes between the droplet bulk and surface, how they interact with one another in each of these phases, and how these phenomena influence the electrospray process.

\section{Acknowledgements}

This work was support by the European Research Council under the European Union's Seventh Framework Program (ERC grant 616551 to VG) and by the Italian Association for Cancer Research (AIRC) (IG-18695 to AR).

\section{References}

1. Gehring, K., Leroy, J.L., Gueron, M.: A tetrameric DNA structure with protonated cytosine.cytosine base pairs. Nature. 363, 561-565 (1993)

2. Leroy, J.L., Gueron, M., Mergny, J.L., Helene, C.: Intramolecular folding of a fragment of the cytosine-rich strand of telomeric DNA into an i-motif. Nucleic Acids Res. 22, 1600-1606 (1994)

3. Gueron, M., Leroy, J.L.: The i-motif in nucleic acids. Curr. Opin. Struct. Biol. 10, 326-331 (2000)

4. Abou Assi, H., Garavis, M., Gonzalez, C., Damha, M.J.: i-Motif DNA: structural features and significance to cell biology. Nucleic Acids Res. 46, 8038-8056 (2018)

5. Wright, E.P., Huppert, J.L., Waller, Z.A.E.: Identification of multiple genomic DNA sequences which form i-motif structures at neutral pH. Nucleic Acids Res. 45, 29512959 (2017)

6. Zeraati, M., Langley, D.B., Schofield, P., Moye, A.L., Rouet, R., Hughes, W.E., Bryan, T.M., Dinger, M.E., Christ, D.: I-motif DNA structures are formed in the nuclei of human cells. Nature Chem. 10, 631-637 (2018)

7. Dzatko, S., Krafcikova, M., Hansel-Hertsch, R., Fessl, T., Fiala, R., Loja, T., Krafcik, D., Mergny, J.L., Foldynova-Trantirkova, S., Trantirek, L.: Evaluation of the Stability of DNA i-Motifs in the Nuclei of Living Mammalian Cells. Angew. Chem. Int. Ed. 57, 2165-2169 (2018)

8. Mergny, J.L., Lacroix, L.: Analysis of Thermal Melting Curves. Oligonucleotides. 13, 515-537 (2003)

9. Kypr, J., Kejnovska, I., Renciuk, D., Vorlickova, M.: Circular dichroism and conformational polymorphism of DNA. Nucleic Acids Res. 37, 1713-1725 (2009) 
10. Phan, A.T., Gueron, M., Leroy, J.L.: The solution structure and internal motions of a fragment of the cytidine-rich strand of the human telomere. J. Mol. Biol. 299, 123-144 (2000)

11. Bowers, M.T., Kemper, P.R., Von Helden, G., Van Koppen, P.A.M.: Gas-Phase Ion Chromatography: Transition Metal State Selection and Carbon Cluster Formation. Science. 260, 1446-1451 (1993)

12. Clemmer, D.E., Hudgins, R.R., Jarrold, M.F.: Naked protein conformations: cytochrome $\mathrm{c}$ in the gas phase. J. Am. Chem. Soc. 117, 10141-10142 (1995)

13. Wyttenbach, T., Von Helden, G., Bowers, M.T.: Gas-Phase Conformation of Biological Molecules: Bradykinin. J. Am. Chem. Soc. 118, 8355-8364 (1996)

14. Clemmer, D.E., Jarrold, M.F.: Ion mobility measurements and their applications to clusters of biomolecules. J. Mass Spectrom. 32, 577-592 (1997)

15. Fenn, J.B., Mann, M., Meng, C.K., Wong, S.F., Whitehouse, C.M.: Electrospray ionization for mass spectrometry. Science. 246, 64-71 (1989)

16. Yamashita, M., Fenn, J.B.: Electrospray ion source. Another variation on the free-jet theme. J. Phys. Chem. 88, 4451-4459 (1984)

17. Fenn, J.B., Mann, M., Meng, C.K., Wong, S.F.: Electrospray ionization-principles and practice. Mass Spectrom. Rev. 9, 37-70 (1990)

18. Chowdhury, S.K., Katta, V., Chait, B.T.: Probing conformational changes in proteins by mass spectrometry. J. Am. Chem. Soc. 112, 9012-9013 (1990)

19. Smith, R.D., Light-Wahl, K.J., Winger, B.E., Loo, J.A.: Preservation of non-covalent associations in electrospray ionization mass spectrometry : multiply charged polypeptide and protein dimers. Org. Mass Spectrom. 27, 811-821 (1992)

20. Leney, A.C., Heck, A.J.R.: Native Mass Spectrometry: What is in the Name? J. Am. Soc. Mass Spectrom. 28, 5-13 (2017)

21. Li, J., Taraszka, J.A., Counterman, A.E., Clemmer, D.E.: Influence of solvent composition and capillary temperature on the conformations of electrosprayed ions: unfolding of compact ubiquitin colformers from pseudonative and denatured solutions. Int. J. Mass Spectrom. 185/186/187, 37-47 (1999)

22. El-Baba, T.J., Woodall, D.W., Raab, S.A., Fuller, D.R., Laganowsky, A., Russell, D.H., Clemmer, D.E.: Melting Proteins: Evidence for Multiple Stable Structures upon Thermal Denaturation of Native Ubiquitin from Ion Mobility Spectrometry-Mass Spectrometry Measurements. J. Am. Chem. Soc. 139, 6306-6309 (2017)

23. Beveridge, R., Covill, S., Pacholarz, K.J., Kalapothakis, J.M., MacPhee, C.E., Barran, P.E.: A mass-spectrometry-based framework to define the extent of disorder in proteins. Anal. Chem. 86, 10979-10991 (2014)

24. Loo, J.A., Ogorzalek Loo, R.R.: Electrospray ionization mass spectrometry of peptides and proteins. In: Cole RB (ed.). Wiley, New York, (1997)

25. Gumerov, D.R., Dobo, A., Kaltashov, I.A.: Protein-ion charge-state distributions in electrospray ionization mass spectrometry: distinguishing conformational distributions from masking effects. Eur. J. Mass Spectrom. 8 123-129 (2002)

26. Li, J., Santambrogio, C., Brocca, S., Rossetti, G., Carloni, P., Grandori, R.: Conformational effects in protein electrospray-ionization mass spectrometry. Mass Spectrom. Rev. 105, 111-122 (2016)

27. Grandori, R.: Origin of the conformation dependence of protein charge-state distributions in electrospray ionization mass spectrometry. J. Mass Spectrom. 38, 1115 (2003)

28. Laszlo, K.J., Munger, E.B., Bush, M.F.: Folding of Protein Ions in the Gas Phase after Cation-to-Anion Proton-Transfer Reactions. J. Am. Chem. Soc. 138, 9581-9588 (2016) 
29. Laszlo, K.J., Bush, M.F.: Interpreting the Collision Cross Sections of Native-like Protein Ions: Insights from Cation-to-Anion Proton-Transfer Reactions. Anal. Chem. 89, 7607-7614 (2017)

30. Pacholarz, K.J., Porrini, M., Garlish, R.A., Burnley, R.J., Taylor, R.J., Henry, A.J., Barran, P.E.: Dynamics of intact immunoglobulin $\mathrm{G}$ explored by drift-tube ionmobility mass spectrometry and molecular modeling. Angew. Chem. Int. Ed. 53, 7765-7769 (2014)

31. Hansen, K., Lau, A.M., Giles, K., McDonnell, J.M., Struwe, W.B., Sutton, B.J., Politis, A.: A Mass-Spectrometry-Based Modelling Workflow for Accurate Prediction of IgG Antibody Conformations in the Gas Phase. Angew. Chem. Int. Ed. in press, 10.1002/anie.201812018 (2018)

32. Porrini, M., Rosu, F., Rabin, C., Darre, L., Gomez, H., Orozco, M., Gabelica, V.: Compaction of Duplex Nucleic Acids upon Native Electrospray Mass Spectrometry. ACS Cent. Sci. 3, 454-461 (2017)

33. Rosu, F., Gabelica, V., Joly, L., Gregoire, G., De Pauw, E.: Zwitterionic i-motif structures are preserved in DNA negatively charged ions produced by electrospray mass spectrometry. Phys. Chem. Chem. Phys. 12, 13448-13454 (2010)

34. Garabedian, A., Butcher, D., Lippens, J.L., Miksovska, J., Chapagain, P.P., Fabris, D., Ridgeway, M.E., Park, M.A., Fernandez-Lima, F.: Structures of the kinetically trapped i-motif DNA intermediates. Phys. Chem. Chem. Phys. 18, 26691-26702 (2016)

35. Cavaluzzi, M.J., Borer, P.N.: Revised UV extinction coefÆcients for nucleoside-5'monophosphates and unpaired DNA and RNA. Nucleic Acids Res. 32, e13 (2004)

36. Marchand, A., Livet, S., Rosu, F., Gabelica, V.: Drift Tube Ion Mobility: How to Reconstruct Collision Cross Section Distributions from Arrival Time Distributions? Anal. Chem. 89, 12674-12681 (2017)

37. D'Atri, V., Porrini, M., Rosu, F., Gabelica, V.: Linking molecular models with ion mobility experiments. Illustration with a rigid nucleic acid structure. J. Mass. Spectrom. 50, 711-726 (2015)

38. Gabelica, V., Livet, S., Rosu, F.: Optimizing Native Ion Mobility Q-TOF in Helium and Nitrogen for Very Fragile Noncovalent Structures. J. Am. Soc. Mass Spectrom. 29, 2189-2198 (2018)

39. Lannes, L., Halder, S., Krishnan, Y., Schwalbe, H.: Tuning the pH Response of iMotif DNA Oligonucleotides. ChemBioChem. 16, 1647-1656 (2015)

40. Mergny, J.L., Lacroix, L., Han, X., Leroy, J.L., Hélène, C.: Intramolecular Folding of Pyrimidine Oligodeoxynucleotides into an i-DNA Motif. J. Am. Chem. Soc. 117, 8887-8898 (1995)

41. Pagano, A., Iaccarino, N., Abdelhamid, M.A.S., Brancaccio, D., Garzarella, E.U., Di Porzio, A., Novellino, E., Waller, Z.A.E., Pagano, B., Amato, J., Randazzo, A.: Common G-Quadruplex Binding Agents Found to Interact With i-Motif-Forming DNA: Unexpected Multi-Target-Directed Compounds. Front. Chem. 6, (2018)

42. Markham, N.R., Zuker, M.: DINAMelt web server for nucleic acid melting prediction. Nucleic Acids Res. 33, W577-581 (2005)

43. Clore, G.M., Gronenborn, A.M.: An investigation into the solution structure of the single-stranded DNA undecamer S'd AAGTGTGATAT by means of nuclear Overhauser enhancement measurements. Eur. Biophys. J. 11, 95-102 (1984)

44. Griffey, R.H., Sasmor, H., Greig, M.J.: Oligonucleotide charge states in negative ionization electrospray - mass spectrometry are a function of solution ammonium ion concentration. J. Am. Soc. Mass Spectrom. 8, 155-160 (1997) 
45. $\mathrm{Xu}, \mathrm{N}$. , Chingin, K., Chen, H.: Ionic strength of electrospray droplets affects charging of DNA oligonucleotides. J. Mass Spectrom. 49, 103-107 (2014)

46. Ren, W., Zheng, K., Liao, C., Yang, J., Zhao, J.: Charge evolution during the unfolding of a single DNA i-motif. Phys. Chem. Chem. Phys. 20, 916-924 (2018)

47. Zhou, S., Prebyl, B.S., Cook, K.D.: Profiling pH changes in the electrospray plume. Anal. Chem. 74 4885-4888 (2002)

48. Girod, M., Dagany, X., Antoine, R., Dugourd, P.: Relation between charge state distributions of peptide anions and $\mathrm{pH}$ changes in the electrospray plume. A mass spectrometry and optical spectroscopy investigation. Int. J. Mass Spectrom. 308, 4148 (2011)

49. Gabelica, V., Baker, E.S., Teulade-Fichou, M.P., De Pauw, E., Bowers, M.T.: Stabilization and structure of telomeric and c-myc region intramolecular Gquadruplexes: The role of central cations and small planar ligands. J. Am. Chem. Soc. 129, 895-904 (2007)

50. Ickert, S., Hofmann, J., Riedel, J., Beck, S., Pagel, K., Linscheid, M.W.: Charge induced geometrical reorganization of DNA oligonucleotides studied by tandem mass spectrometry and ion mobility. Eur. J. Mass Spectrom. 24, 225-230 (2018)

51. Ogorzalek Loo, R.R., Lakshmanan, R., Loo, J.A.: What protein charging (and supercharging) reveal about the mechanism of electrospray ionization. J. Am. Soc. Mass Spectrom. 25, 1675-1693 (2014)

52. Lipfert, J., Doniach, S., Das, R., Herschlag, D.: Understanding nucleic acid-ion interactions. Annu. Rev. Biochem. 83, 813-841 (2014)

53. Enke, C.G.: A predictive model for matrix and analyte effects in electrospray ionization of singly-charged ionic analytes. Anal. Chem. 69, 4885-4893 (1997)

54. Constantopoulos, T.L., Jackson, G.S., Enke, C.G.: Effects of Salt Concentration on Analyte Response Using Electrospray Ionization Mass Spectrometry. J. Am. Soc. Mass Spectrom. 10, 625-634 (1999)

55. Konermann, L., Ahadi, E., Rodriguez, A.D., Vahidi, S.: Unraveling the mechanism of electrospray ionization. Anal. Chem. 85, 2-9 (2013)

56. Lin, H., Kitova, E.N., Johnson, M.A., Eugenio, L., Ng, K.K., Klassen, J.S.: Electrospray ionization-induced protein unfolding. J. Am. Soc. Mass Spectrom. 23, 2122-2131 (2012) 